\title{
Synthesis of fused tricyclic amines unsubstituted at the ring-junction positions by a cascade condensation, cyclization, cycloaddition then decarbonylation strategy
}

\author{
lain Coldham ${ }^{* 1}$, Adam J. M. Burrell ${ }^{1}$, Hélène D. S. Guerrand ${ }^{1}$, \\ Luke Watson ${ }^{1}$, Nathaniel G. Martin ${ }^{2}$ and Niall Oram ${ }^{3}$
}

\section{Full Research Paper}

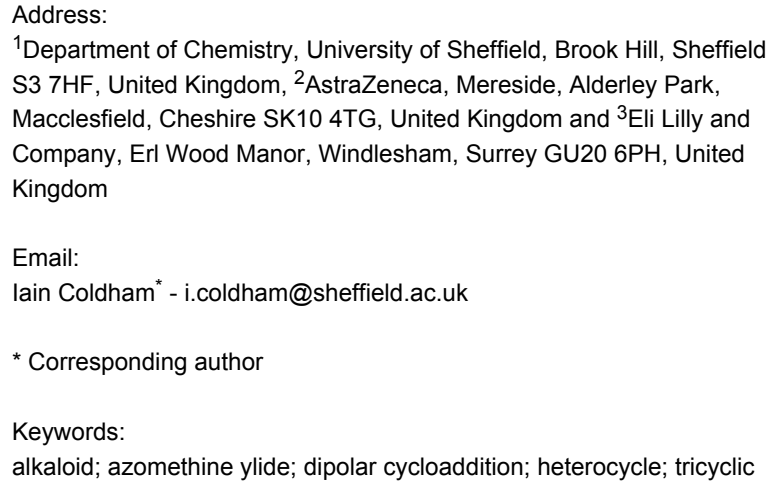

${ }^{1}$ Department of Chemistry, University of Sheffield, Brook Hill, Sheffield S3 7HF, United Kingdom, ${ }^{2}$ AstraZeneca, Mereside, Alderley Park, Macclesfield, Cheshire SK10 4TG, United Kingdom and ${ }^{3}$ Eli Lilly and Company, Erl Wood Manor, Windlesham, Surrey GU20 6PH, United Kingdom

Email:

lain Coldham* - i.coldham@sheffield.ac.uk

* Corresponding author

Keywords:

alkaloid; azomethine ylide; dipolar cycloaddition; heterocycle; tricyclic

\author{
Beilstein J. Org. Chem. 2012, 8, 107-111. \\ doi:10.3762/bjoc.8.11 \\ Received: 01 November 2011 \\ Accepted: 23 December 2011 \\ Published: 18 January 2012 \\ Associate Editor: J. N. Johnston \\ (C) 2012 Coldham et al; licensee Beilstein-Institut. \\ License and terms: see end of document.
}

\begin{abstract}
Heating aldehydes that contain a protected hydroxymethyl group, a tethered alkyl chloride and a tethered alkenyl group at the $\alpha$-position of the aldehyde with an amine sets up a cascade (tandem) reaction sequence involving condensation to an intermediate imine, then cyclization and formation of an intermediate azomethine ylide and then intramolecular dipolar cycloaddition. The fused tricyclic products are formed with complete or very high stereochemical control. The hydroxymethyl group was converted into an aldehyde - which could be removed to give the tricyclic amine products that are unsubstituted at the ring junction positions - or was converted into an alkene, which allowed the formation of the core ring system of the alkaloids scandine and meloscine.
\end{abstract}

\section{Introduction}

Cascade reaction sequences [1] provide a rapid and efficient means to build complexity in organic chemistry. One such sequence involves a cyclization followed by in situ intramolecular cycloaddition to give three new rings in a single transformation [2-8]. We have been studying the intramolecular dipolar cycloaddition of azomethine ylides in syn- thesis [9-16] and were able to show that the azomethine ylide could be prepared in situ by a cyclization step [17,18]; for example, by heating the aldehyde $1(\mathrm{R}=\mathrm{Et})$ with glycine ethyl ester to give the tricyclic product $2[19,20]$ (Scheme 1). In this chemistry, the intermediate imine undergoes cyclization onto the tethered alkyl chloride to give an iminium ion which depro- 
tonates to give an azomethine ylide that undergoes dipolar cycloaddition with the alkene. A single stereoisomer of product 2 was formed. Alternatively, glycine could be used and led to a tricyclic product via an intermediate azomethine ylide formed by decarboxylation. Unfortunately, when the substrate $\mathbf{1}$ $(\mathrm{R}=\mathrm{H})$ was used, heating with glycine or glycine ethyl ester did not yield the desired tricyclic products due to competing enamine formation [21].

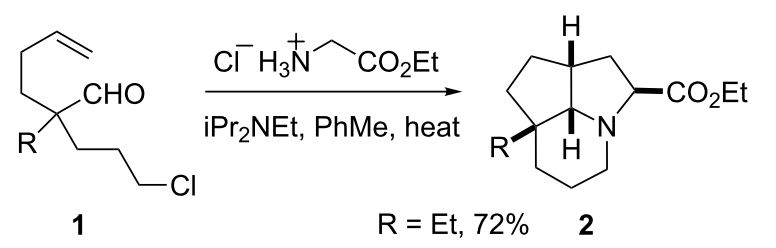

Scheme 1: Cascade chemistry for 2-ethyl-aldehydes.

For this cascade cyclization-cycloaddition chemistry to be widely applicable (for example for the preparation of alkaloids), we need to be able to access tricyclic products with no substituents (only hydrogen atoms) at the ring junction positions (such as compound $\mathbf{2}, \mathrm{R}=\mathrm{H}$, or other ring sizes) [22]. This paper outlines an approach to such targets using a substituent (to block side reactions) which can then be removed by decarbonylation [23].

\section{Results and Discussion Preparation of the aldehyde substrates}

We decided to incorporate a one-carbon substituent, alpha to the aldehyde group, that could potentially be removed after the cascade cyclization-cycloaddition chemistry. Starting from nitrile 3, we prepared three different aldehydes, as shown in Scheme 2 and Scheme 3. Double deprotonation (of the alcohol and alpha to the nitrile) of substrate $\mathbf{3}$ and C-alkylation occurred smoothly to give $\mathbf{4 a}$ or $\mathbf{4 b}$ ( $n=1$ or 2 , respectively). A second double deprotonation and then an alkylation with bromochloropropane gave 5a and 5b. Oxidation of the alcohol 5a $(n=1)$ gave the aldehyde $\mathbf{6}$. Alternatively, protection of $\mathbf{5 a}$ and $\mathbf{5 b}$ as their tert-butyldimethylsilyl ethers gave $\mathbf{7 a}$ and $\mathbf{7 b}$. DIBAL-H reduction of nitrile $\mathbf{7 b}(n=2)$ gave aldehyde $\mathbf{8 b}$. The same reduction of nitrile $7 \mathbf{a}$ gave a low yield of the desired aldehyde 8a; so, an alternative strategy to prepare the aldehyde with one less methylene group in the side-chain was studied (Scheme 3). Alkylation of the commercially available substituted malonate 9 gave product $\mathbf{1 0}$ together with diethyl cyclobutanedicarboxylate (formed by cyclization of the malonate anion onto the internal alkyl chloride). This by-product was removed by

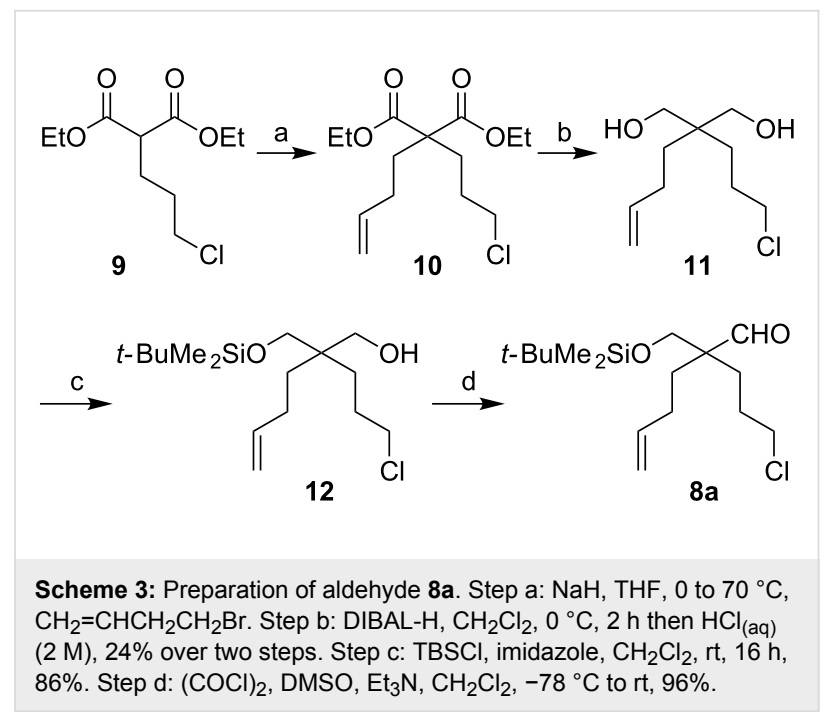

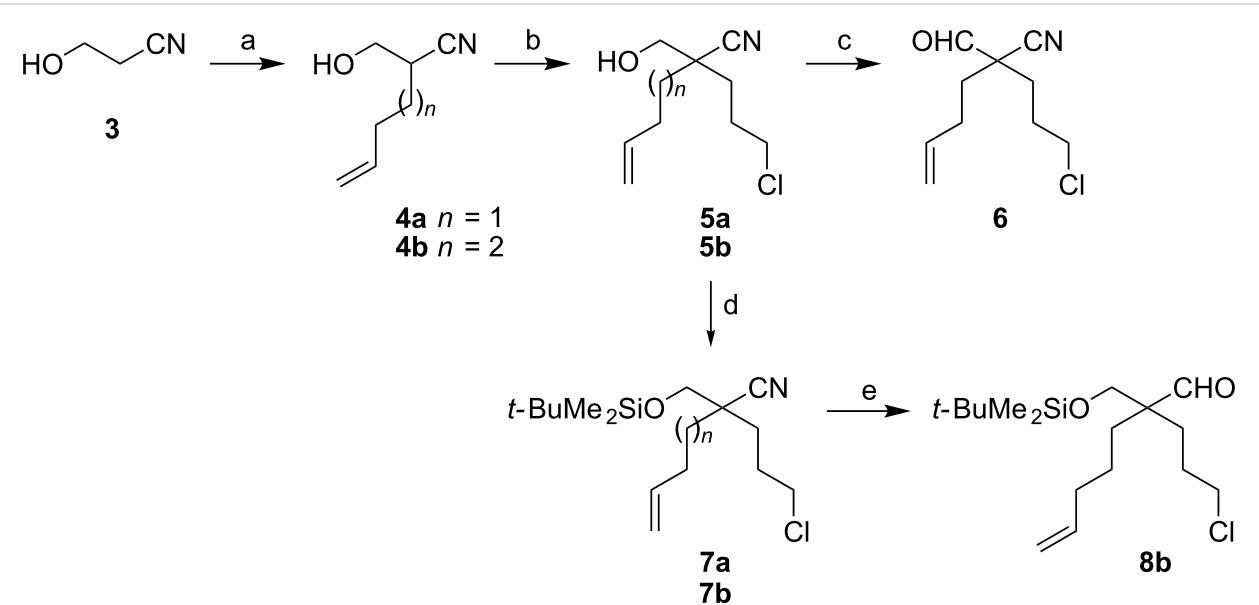

Scheme 2: Preparation of aldehydes 6 and 8b. Step a: LDA, THF, $0{ }^{\circ} \mathrm{C}, \mathrm{CH}_{2}=\mathrm{CHCH}_{2}\left(\mathrm{CH}_{2}\right){ }_{n} \mathrm{Br}(n=1,56 \% ; n=2,76 \%)$. Step b: LDA, THF, $-78{ }^{\circ} \mathrm{C}$, $\mathrm{ClCH}_{2} \mathrm{CH}_{2} \mathrm{CH}_{2} \mathrm{Br}(n=1,80 \% ; n=2,89 \%)$. Step c: Using $5 \mathrm{a},(\mathrm{COCl})_{2}, \mathrm{DMSO}, \mathrm{Et}_{3} \mathrm{~N}, \mathrm{CH}_{2} \mathrm{Cl}_{2},-78{ }^{\circ} \mathrm{C}$ to rt, $92 \%$. Step d: TBSCl, imidazole, $\mathrm{CH}_{2} \mathrm{Cl}_{2}, \mathrm{rt}$, $16 \mathrm{~h}(n=1,92 \% ; n=2,94 \%)$. Step e: Using $7 \mathrm{~b}, \mathrm{DIBAL}-\mathrm{H}, \mathrm{CH}_{2} \mathrm{Cl}_{2},-78{ }^{\circ} \mathrm{C}, 2 \mathrm{~h}$ then $\mathrm{HCl}_{(\mathrm{aq})}(2 \mathrm{M}), 62 \%$. 
column chromatography after reduction of both esters to give diol 11. Mono-protection gave the alcohol 12 which was oxidized to aldehyde $\mathbf{8 a}$.

\section{Cascade condensation, cyclization, cyclo- addition}

The cascade tricyclic ring formation was then investigated with the aldehydes $\mathbf{6 , 8 a}$ and $\mathbf{8 b}$. Heating aldehyde $\mathbf{6}$ with glycine gave a mixture of unidentifiable products. However, heating with glycine ethyl ester in toluene gave the desired tricyclic product 13a as the major stereoisomer, together with a small amount of the separable stereosiomer 13b (Scheme 4). The major isomer 13a was assumed to have the all-cis configuration based on related chemistry (compare with product 2 [19,20], Scheme 1). The minor isomer was assigned by NOESY studies, in which there was a strong enhancement between the ring junction protons and a strong enhancement between the proton alpha to the ester and the ring junction proton alpha to the nitrogen. The reaction is supposed to proceed by initial imine formation, then cyclization with displacement of chloride to give an iminium ion. Deprotonation of this iminium ion would give the azomethine ylide that undergoes intramolecular cycloaddition. The preference for the all-cis isomer 13a arises from a preference for cycloaddition from the conformation shown in Scheme 4. Unfortunately, we were not able to remove the nitrile substituent from the product 13a using lithium in ammonia [24], which instead converted the ethyl ester to its primary carboxylic amide, or using DIBAL-H, which gave a complex mixture of products.

Heating aldehyde $\mathbf{8 a}$ with glycine gave cycloadduct $\mathbf{1 4}$ as a single diastereoisomer (Scheme 5). Deprotection of the silyl ether with tetra- $n$-butylammonium fluoride (TBAF) gave the alcohol 15, then Swern oxidation yielded aldehyde 16. The stereochemistry of alcohol 15 was confirmed by single crystal $\mathrm{X}$-ray analysis. This stereochemistry was expected for these cascade reactions, in which the substituent alpha to the aldehyde (in this case the $\mathrm{TBSOCH}_{2}$ group) is located in the transition state $c i s$ to the developing ring junction protons. The next step, to remove the one-carbon unit to provide the desired tricyclic product with all ring-junction protons, was a decarbon- ylation and this type of reaction is known using Wilkinson's catalyst [25]. We were disappointed to find that attempts to conduct this decarbonylation using aldehyde 16 and $\left[\mathrm{Rh}\left(\mathrm{PPh}_{3}\right)_{3} \mathrm{Cl}\right]$ resulted only in decomposition.

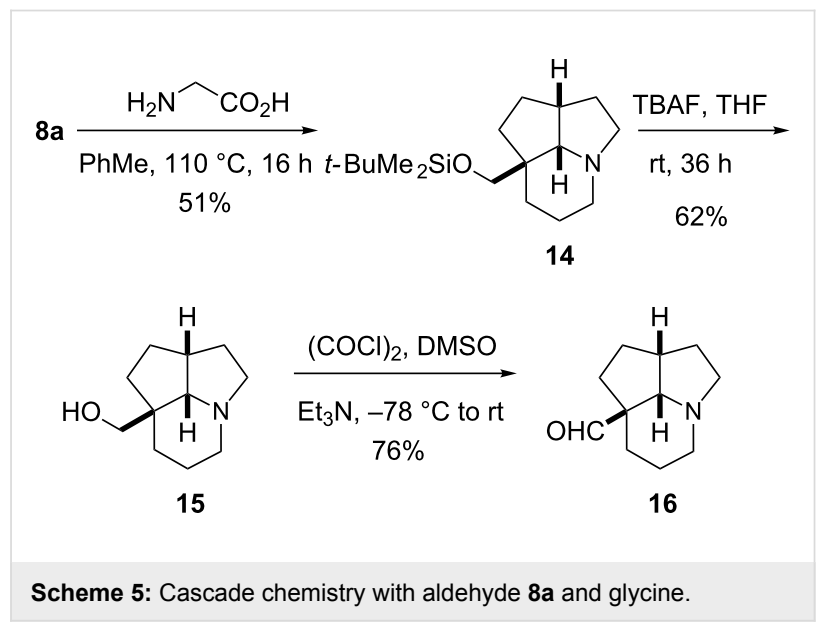

As an aside, we were interested in using the products of this chemistry for the construction of the core ring system found in alkaloid natural products. Wittig reaction with aldehyde $\mathbf{1 6}$ should be possible to provide the core ring system found in the alkaloids meloscine and scandine [26-30]. However, we chose to investigate a shorter reaction sequence without the need for protecting groups and to carry out the Wittig reaction at an earlier stage, as shown in Scheme 6. Olefination of aldehyde 6 with the anion formed from methyltriphenylphosphonium bromide gave alkene 17, which was reduced with DIBAL-H to give aldehyde 18. Heating this aldehyde with glycine in toluene gave the desired tricyclic product $\mathbf{1 9}$ as a single stereoisomer. NOESY studies verified the stereochemistry as shown. Only one of the two alkene groups acts as the dienophile, as expected for conformational reasons. This synthesis (six steps from nitrile 3) represents an efficient entry to the core of the alkaloids meloscine and scandine, which contains the same fused tricyclic ring system.

The use of glycine to form a 'non-stabilized' ylide had led to the desired cycloadduct $\mathbf{1 4}$, although subsequent decarbon-

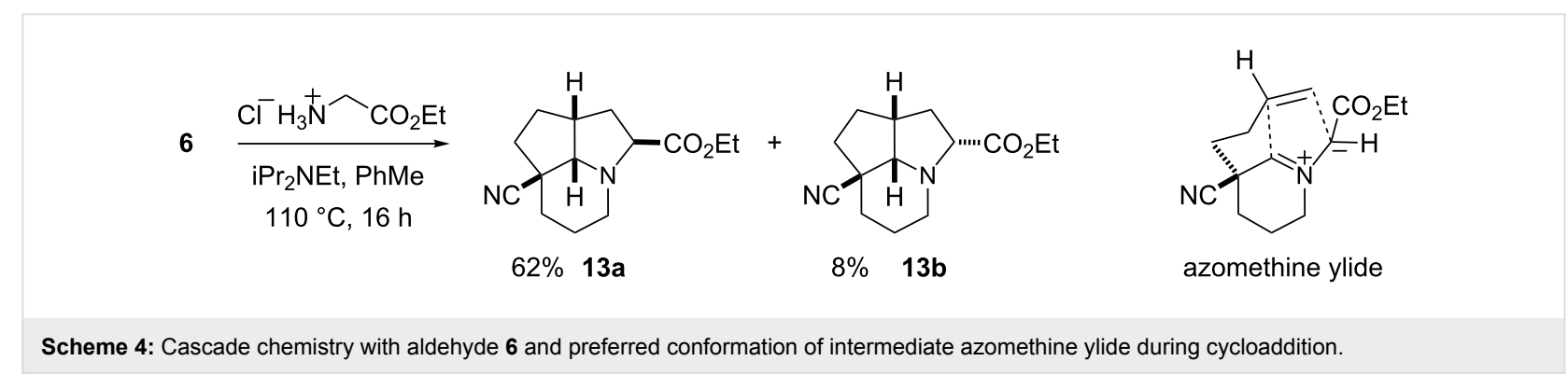




$$
\underset{\mathrm{THF},-78{ }^{\circ} \mathrm{C} \text { to rt }}{\stackrel{\mathrm{MePPh}}{7} \mathrm{Br}, \mathrm{KO}-\mathrm{Bu}}
$$

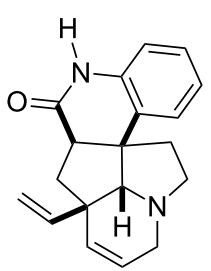

meloscine

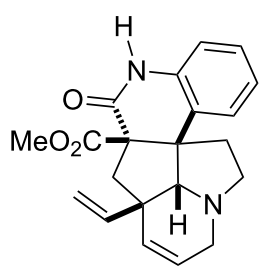

scandine
Scheme 6: Synthesis of the core tricyclic ring system of meloscine and scandine.

ylation had not been successful using aldehyde $\mathbf{1 6}$ (Scheme 5). Despite this, we chose to investigate the cascade chemistry using glycine ethyl ester (to form a 'stabilized' ylide), followed by possible later decarbonylation.

Heating aldehydes $8 \mathbf{a}$ or $\mathbf{8 b}$ with glycine ethyl ester in toluene gave the expected tricyclic products (Scheme 7). Using aldehyde 8a, a single stereoisomer was formed (assumed to have the all-cis configuration shown and confirmed by NOESY studies). Using aldehyde $\mathbf{8 b}$, the major product was the stereoisomer 21, which was expected based on related chemistry [19] and verified by the large coupling constant in the ${ }^{1} \mathrm{H}$ NMR spectrum for the ring junction proton alpha to the nitrogen atom $(2.20 \mathrm{ppm}$, doublet, $J=11.5 \mathrm{~Hz}$ ). However, this transformation was not entirely stereoselective and a (separable) mixture of two other stereoisomers $\mathbf{2 2}$ and $\mathbf{2 3}$ was also formed (NOESY studies were used to ascertain the relative stereochemistry).

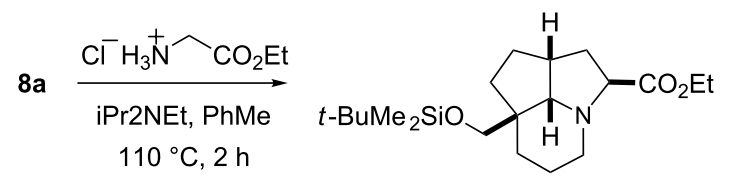
$83 \% 20$

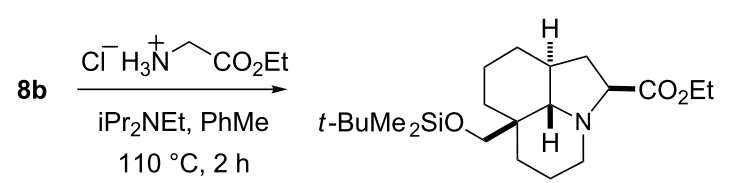
$62 \% 21$

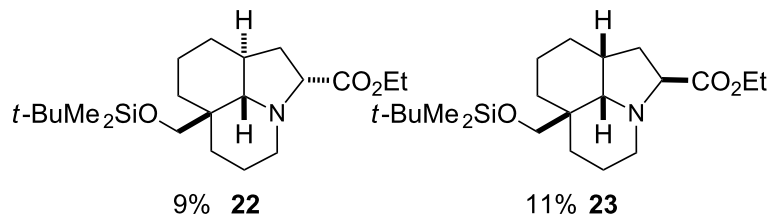

Scheme 7: Cascade chemistry with aldehydes $\mathbf{8 a}$ and $\mathbf{8 b}$ and glycine ethyl ester.

To complete the desired aim to provide a method to prepare fused tricyclic products with all ring-junction protons, we carried out the transformations shown in Scheme 8. Desilylation of $\mathbf{2 0}$ and $\mathbf{2 1}$ gave the alcohols $\mathbf{2 4}$ and 27, respectively. Swern oxidation then gave the aldehydes $\mathbf{2 5}$ and $\mathbf{2 8}$. Finally, using Wilkinson's catalyst, we were pleased to find that both these aldehyde substrates were amenable to decarbonylation. The optimum conditions were found to be a temperature of about $150{ }^{\circ} \mathrm{C}$ for about $2 \mathrm{~h}$. The decarbonylation occurred with overall retention of stereochemistry, as verified by NOESY studies. The presence of the ethyl ester substituent must be

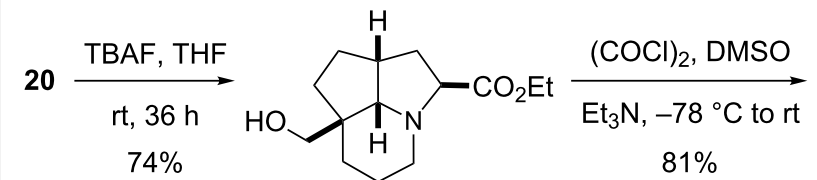

24

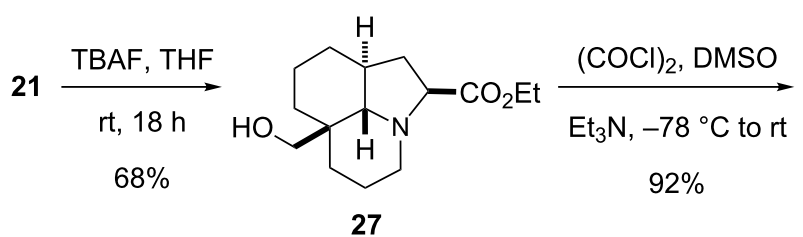<smiles>CCOC(=O)C1CC2CCC3(C=O)CCCN(C2)C13c1ccccc1</smiles>

25<smiles>CCOC(=O)C1C[C@H]2CCC[C@]3(C=O)[C@H](c4ccccc4)N2CCC[C@H]13</smiles>

28<smiles>CCOC[C@@]12C(OCC)C[C@H]1CC[C@H]1CCCN2C1</smiles>

26<smiles></smiles>

29

Scheme 8: Decarbonylation reactions to give the products 26 and 29. 
sufficient to allow a successful decarbonylation (in comparison with substrate 16), possibly due to the reduced ability of the amine nitrogen atom to coordinate to the rhodium complex.

\section{Conclusion}

The chemistry described here provides a method to prepare fused tricyclic products in which the ring junction positions are unsubstituted. Problems with conducting the cascade condensation, cyclisation, cycloaddition chemistry using azomethine ylides derived from enolisable aldehyde substrates [21] has been circumvented by incorporating a one-carbon unit at the alpha-position of the aldehyde. This one-carbon unit can be removed in certain cases using a decarbonylation reaction.

\section{Supporting Information}

\section{Supporting Information File 1}

Experimental procedures and spectroscopic data.

[http://www.beilstein-journals.org/bjoc/content/

supplementary/1860-5397-8-11-S1.pdf]

\section{Acknowledgements}

We thank the EPSRC (grant EP/F06313X/1), the University of Sheffield, Lilly UK and AstraZeneca for support of this work. Harry Adams (University of Sheffield) is thanked for X-ray crystallographic studies.

\section{References}

1. Nicolaou, K. C.; Chen, J. S. Chem. Soc. Rev. 2009, 38, 2993. doi:10.1039/b903290h

2. Brasholz, M.; Macdonald, J. M.; Saubern, S.; Ryan, J. H.; Holmes, A. B. Chem.-Eur. J. 2010, 16, 11471. doi:10.1002/chem.201001435

3. Brasholz, M.; Johnson, B. A.; Macdonald, J. M.; Polyzos, A.; Tsanaktsidis, J.; Saubern, S.; Holmes, A. B.; Ryan, J. H. Tetrahedron 2010, 66, 6445. doi:10.1016/j.tet.2010.04.092

4. Flick, A. C.; Caballero, M. J. A.; Padwa, A. Tetrahedron 2010, 66, 3643. doi:10.1016/j.tet.2010.03.088

5. Flick, A. C.; Caballero, M. J. A.; Lee, H. I.; Padwa, A. J. Org. Chem. 2010, 75, 1992. doi:10.1021/jo100055u

6. Stearman, C. J.; Wilson, M.; Padwa, A. J. Org. Chem. 2009, 74, 3491. doi:10.1021/j09003579

7. Karatholuvhu, M. S.; Sinclair, A.; Newton, A. F.; Alcaraz, M.-L.; Stockman, R. A.; Fuchs, P. L. J. Am. Chem. Soc. 2006, 128, 12656. doi:10.1021/ja065015x

8. Padwa, A. Chem. Soc. Rev. 2009, 38, 3072. doi:10.1039/b816701j

9. Coldham, I.; Hufton, R. Chem. Rev. 2005, 105, 2765. doi:10.1021/cr040004c

10. Burrell, A. J. M.; Coldham, I. Curr. Org. Synth. 2010, 7, 312. doi:10.2174/157017910791414472

11. Coldham, I.; Coles, S. J.; Crapnell, K. M.; Fernàndez, J.-C.; Haxell, T. F. N.; Hursthouse, M. B.; Moseley, J. D.; Treacy, A. B. Chem. Commun. 1999, 1757. doi:10.1039/a904667d
12. Coldham, I.; Crapnell, K. M.; Fernàndez, J.-C.; Moseley, J. D.; Rabot, R. J. Org. Chem. 2002, 67, 6181. doi:10.1021/jo016376s

13. Coldham, I.; Pih, S. M.; Rabot, R. Synlett 2005, 1743. doi:10.1055/s-2005-871538

14. Coldham, I.; Dobson, B. C.; Franklin, A. I.; Fletcher, S. R. Tetrahedron Lett. 2007, 48, 873. doi:10.1016/j.tetlet.2006.11.130

15. Coldham, I.; Dobson, B. C.; Fletcher, S. R.; Franklin, A. I. Eur. J. Org. Chem. 2007, 2676. doi:10.1002/ejoc.200700045

16. Franklin, A. I.; Bensa, D.; Adams, H.; Coldham, I. Org. Biomol. Chem. 2011, 9, 1901. doi:10.1039/c0ob01019g

17. Pearson, W. H.; Stoy, P.; Mi, Y. J. Org. Chem. 2004, 69, 1919. doi:10.1021/jo030334h

18. Pearson, W. H.; Kropf, J. E.; Choy, A. L.; Lee, I. Y.; Kampf, J. W. J. Org. Chem. 2007, 72, 4135. doi:10.1021/jo0703799

19. Coldham, I.; Burrell, A. J. M.; White, L. E.; Adams, H.; Oram, N. Angew. Chem., Int. Ed. 2007, 46, 6159. doi:10.1002/anie.200701943

20. Burrell, A. J. M.; Coldham, I.; Watson, L.; Oram, N.; Pilgram, C. D.; Martin, N. G. J. Org. Chem. 2009, 74, 2290. doi:10.1021/j08019913

21. Burrell, A. J. M.; Coldham, I.; Oram, N. Org. Lett. 2009, 11, 1515. doi:10.1021/ol9001653

22. Burrell, A. J. M.; Watson, L.; Martin, N. G.; Oram, N.; Coldham, I. Org. Biomol. Chem. 2010, 8, 4530. doi:10.1039/c0ob00408a

23. Coldham, I.; Burrell, A. J. M.; Watson, L.; Oram, N.; Martin, N. G. Heterocycles 2012, 84, 597. doi:10.3987/COM-11-S(P)29 (Example for a desulfurization).

24. Vilsmaier, E.; Milch, G.; Bergsträßer, T. Tetrahedron 1998, 54, 6403. doi:10.1016/S0040-4020(98)00298-1

25. Tsuji, J.; Ohno, K. Synthesis 1969, 157. doi:10.1055/s-1969-34197

26. Hugel, G.; Levy, J. J. Org. Chem. 1986, 51, 1594. doi:10.1021/jo00359a040

27. Zhang, H.; Curran, D. P. J. Am. Chem. Soc. 2011, 133, 10376. doi:10.1021/ja2042854

28. Hayashi, Y.; Inagaki, F.; Mukai, C. Org. Lett. 2011, 13, 1778. doi:10.1021/ol200311y

29. Selig, P.; Herdtweck, E.; Bach, T. Chem.-Eur. J. 2009, 15, 3509. doi:10.1002/chem.200802383

30. Overman, L. E.; Robertson, G. M.; Robichaud, A. J. J. Am. Chem. Soc. 1991, 113, 2598. doi:10.1021/ja00007a038

\section{License and Terms}

This is an Open Access article under the terms of the Creative Commons Attribution License (http://creativecommons.org/licenses/by/2.0), which permits unrestricted use, distribution, and reproduction in any medium, provided the original work is properly cited.

The license is subject to the Beilstein Journal of Organic Chemistry terms and conditions: (http://www.beilstein-journals.org/bjoc)

The definitive version of this article is the electronic one which can be found at: doi:10.3762/bjoc.8.11 